\title{
Trachemys gaigeae (Hartweg 1939) - \\ Big Bend Slider, Mexican Plateau Slider, Jicotea de la Meseta Mexicana
}

\author{
JAMES N. STUART ${ }^{1}$ AND Joseph P. WARD ${ }^{2}$ \\ ${ }^{1}$ New Mexico Department of Game \& Fish, Conservation Services Division, \\ P.O. Box 25112, Santa Fe, New Mexico87504USA [james.stuart@state.nm.us]; \\ ${ }^{2} 6899$ South Highway A1A, Melbourne Beach, Florida 32951 USA [jpwtct@att.net]
}

Summary. - The Big Bend slider, Trachemys gaigeae (Family Emydidae), is a medium-sized freshwater turtle (carapace length to $308 \mathrm{~mm}$ ) that is limited to riverine areas of the desert southwestern United States and northern Mexico. Two allopatric subspecies are currently recognized, $T$. g. gaigeae and T. g. hartwegi, which might represent distinct species. Degradation and fragmentation of riverine habitat is likely the most significant threat to T. gaigeae in both the United States and Mexico. Overcollecting for the pet trade or as food and hybridization with introduced Trachemys scripta are also of concern, although more information is needed. Commercial collection is prohibited in the United States but otherwise this slider receives little protection, except where it occurs on public lands. The species uses reservoirs and artificial ponds in New Mexico, suggesting some adaptability to human-modified environments. The status and ecology of this species in the United States has been little studied until recently and even less is known about populations in Mexico.

Distribution. - Mexico, USA. Occurs in the Rio Grande (= Río Bravo del Norte) drainage from south-central New Mexico downstream to western Texas and northwestern Coahuila, the Río Conchos in Mexico from southern Chihuahua downstream to the confluence with the Rio Grande, and the Río Nazas closed basin of Durango and Coahuila, Mexico.

Synonymy. - Pseudemys scripta gaigeae Hartweg 1939, Pseudemys gaigeae, Chrysemys scripta gaigeae, Chrysemys gaigeae, Chrysemys (Trachemys) scripta gaigeae, Trachemys nebulosa gaigeae, Trachemys scripta gaigeae, Trachemys gaigeae.

SuBSPECIES. - Two currently recognized: Trachemys gaigeae gaigeae (Big Bend Slider, Jicotea de Gaige) and Trachemys gaigeae hartwegi (Nazas Slider, Jicotea del Nazas) (synonymy: Pseudemys scripta hartwegi Legler 1990, Chrysemys scripta hartwegi, Trachemys scripta hartwegi, Trachemys nebulosa hartwegi, Trachemys ornata hartwegi, Trachemys hartwegi).

STATUS. -IUCN 2009 Red List: Vulnerable (VU A1c,D2) (assessed 1996, needs updating); CITES: Not Listed; US ESA: Not Listed; New Mexico: Species of Greatest Conservation Need.

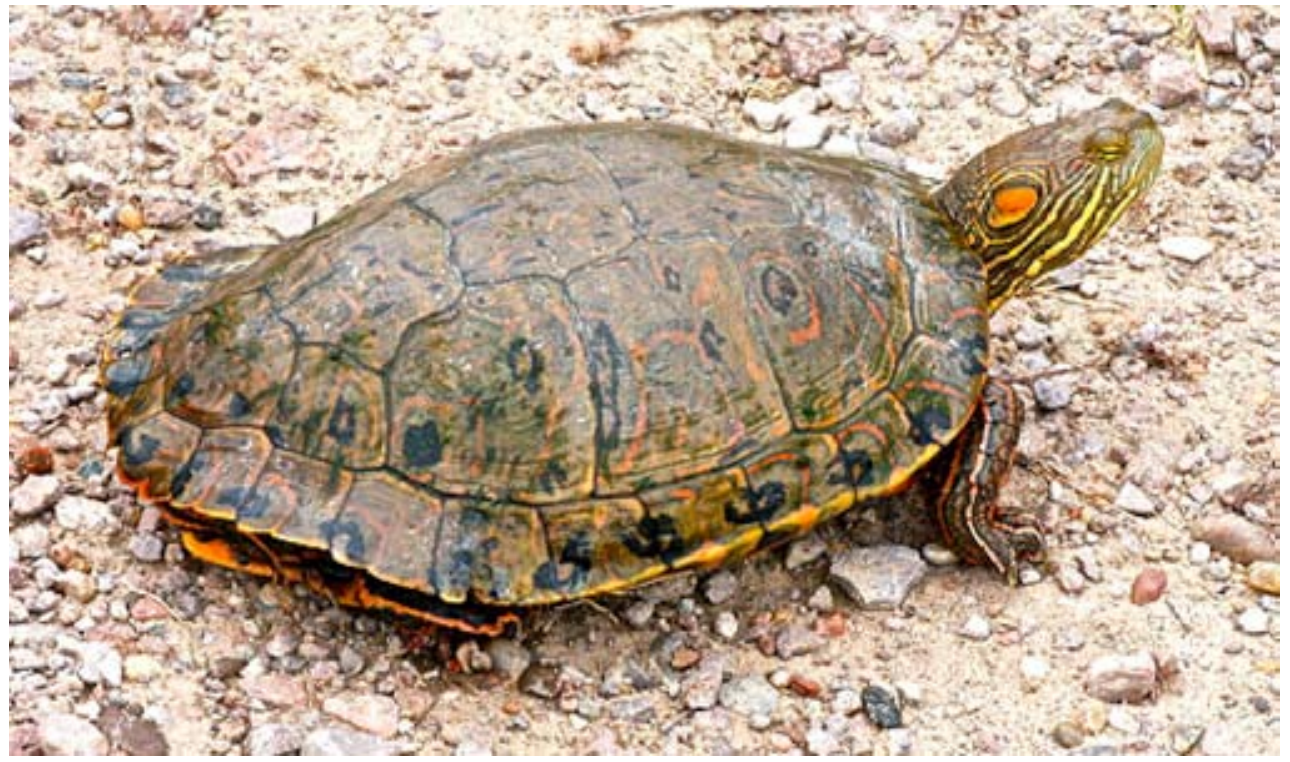

Figure 1. Trachemys gaigeae gaigeae, adult female, from Socorro County, New Mexico, USA. Photo by J.N. Stuart. 
Taxonomy. - Trachemys gaigeae, currently considered to include two subspecies, T. g. gaigeae and T. g. hartwegi, was described as Pseudemys scripta gaigeae by Hartweg (1939) based on a holotype from the Rio Grande at Boquillas, Brewster County, Texas. Specimens from the Río Nazas population, Mexico, currently assigned to T. g. hartwegi (Legler 1990), were included as paratypes in the original description. The synonymy for the species is complicated by the fact that, since its description, $T$. gaigeae has been assigned to three different genera and three other species, and the specific name has frequently been misspelled as gaigei, gaigea, or gaigae (Stuart and Ernst 2004; Fritz and Havaš 2007).

Trachemys gaigeae has been considered by some a member of a Mesoamerican or Neotropical group of sliders (e.g., Legler 1990) or allied with cooters (Pseudemys spp.;
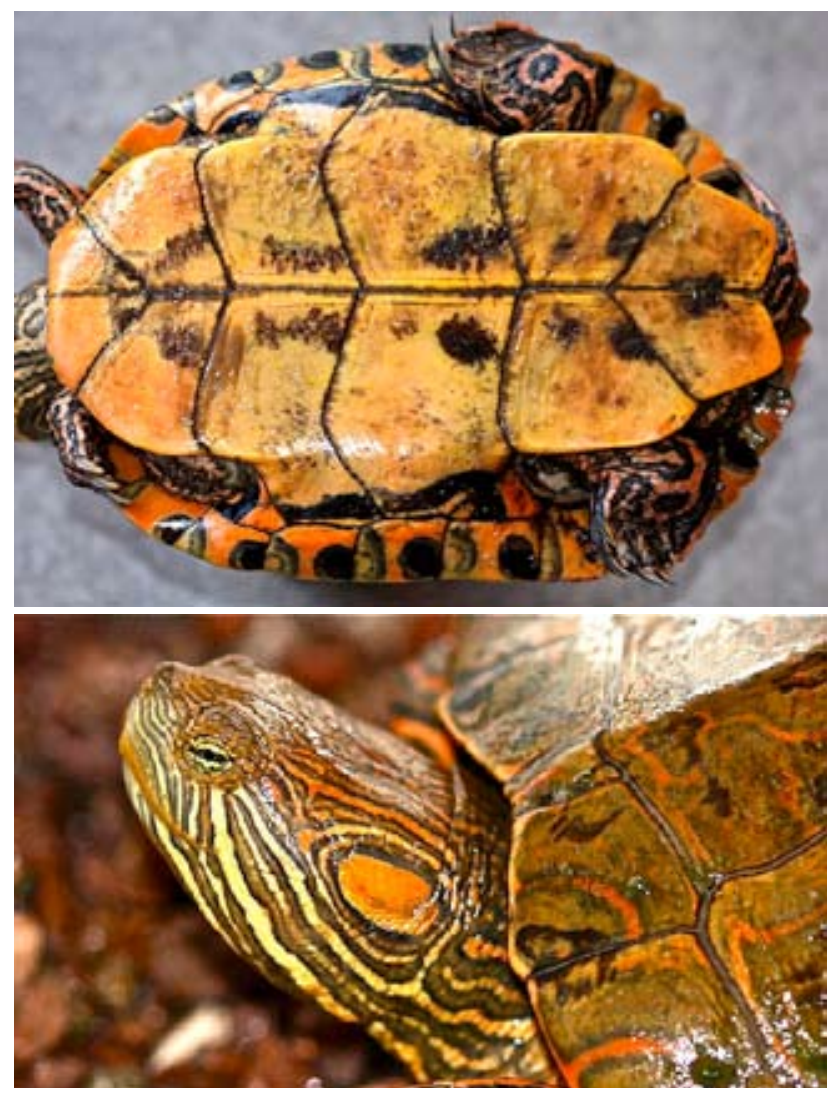

Figure 2. Trachemys gaigeae gaigeae, plastron and head of adult female, from Socorro County, New Mexico, USA. Photos by J.N. Stuart.

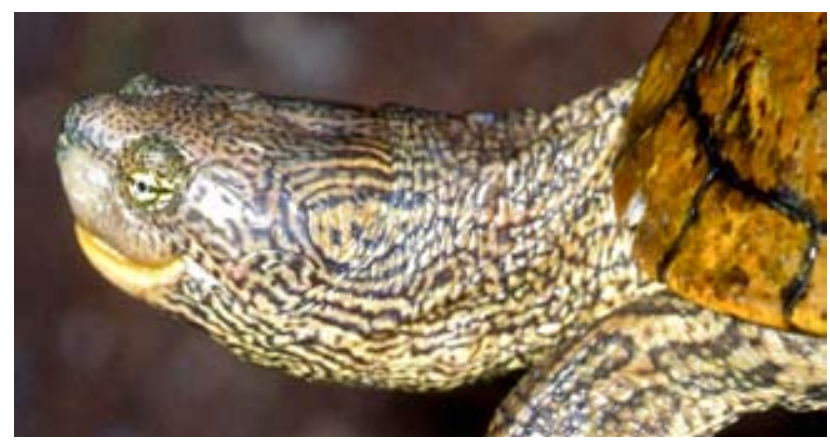

Figure 3. Trachemys gaigeae gaigeae, melanistic adult male, from New Mexico, USA. Photo by C.W. Painter.
Holman 1977). More recently, Jackson et al. (2008) and Forstner et al. (in press) placed T. gaigeae within a North American clade of sliders alongside T. scripta (sensu stricto), an arrangement suggested earlier by Starkey (1997). Many authors have classified gaigeae, and later hartwegi, as subspecies of T. scripta (e.g., Moll and Legler 1971, Ernst 1990, Legler 1990, Iverson 1992), if only for practical purposes pending further study. Others have attempted to reconcile the distinctiveness of this form from T. scripta, either by recognizing gaigeae as a monotypic or polytypic species (e.g., Stejneger and Barbour 1939, Weaver and Rose 1967, Price and Hillis 1989, Ernst 1992, Seidel et al. 1999) or by assigning gaigeae and hartwegi to earlier described Mesoamerican taxa such as T. nebulosa (Ward 1980, 1984; Bonin et al. 1996, 2006; Bringsøe 2001) or T. ornata (Walls 1996). Despite differences in genetics, morphology, and courtship behavior (Seidel et al. 1999), some hybridization occurs between $T$. gaigeae and T. scripta (sensu stricto) where they occur in syntopy (see below). However, no intergrade zone apparently exists in the Rio Grande downstream of the Big Bend region, Texas, where native T. s. elegans also occurs (Seidel et al. 1999, Forstner et al. in press).

Herein, we follow the nomenclatural arrangement proposed by Seidel (2002) and used by Stuart and Ernst (2004), Vetter (2004), Fritz and Havaš (2007), Iverson et al. (2008), Ernst and Lovich (2009), and Seidel and Ernst (in press). Ward (1980) found that based on skull and skeletal characteristics that hartwegi may be closer to West Coast populations of Trachemys than to T. gaigeae. Jackson et al. (2008) provided additional genetic evidence for recognizing T. gaigeae as a distinct species, but did not address the placement of hartwegi. Preliminary mtDNA data provided by Forstner et al. (in press) suggests that $T$. g. hartwegi might be more closely related to $T$. venusta cataspila than to T. g. gaigeae, and Stephens and Wiens (2003) concluded that gaigeae and hartwegi belong to different clades within Trachemys.Lemos Espinal and Smith (2007b) also questioned whether these two taxa are conspecific.

The Río Nazas closed basin, and its population of $T$. g. hartwegi, is separated from drainages that support other Trachemys by at least $15 \mathrm{~km}$ of semi-arid, mountainous

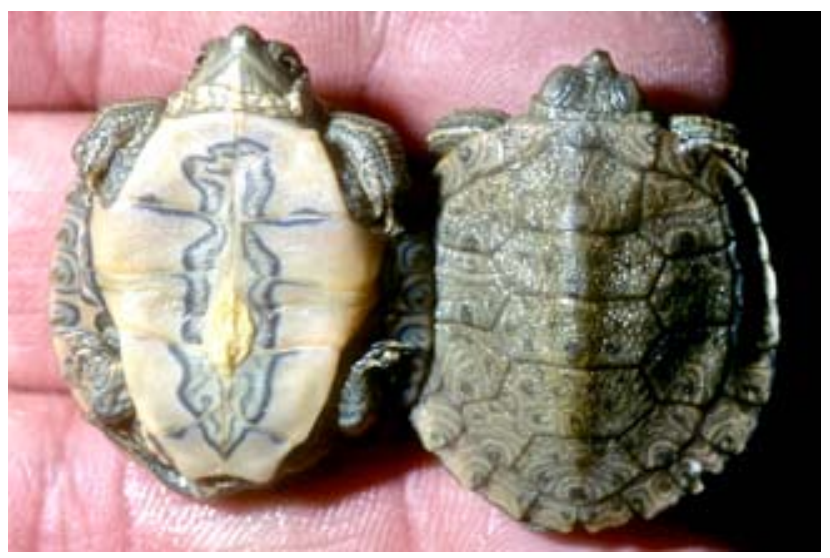

Figure 4. Trachemys gaigeae gaigeae, hatchlings, from New Mexico, USA. Photo by C.W. Painter. 


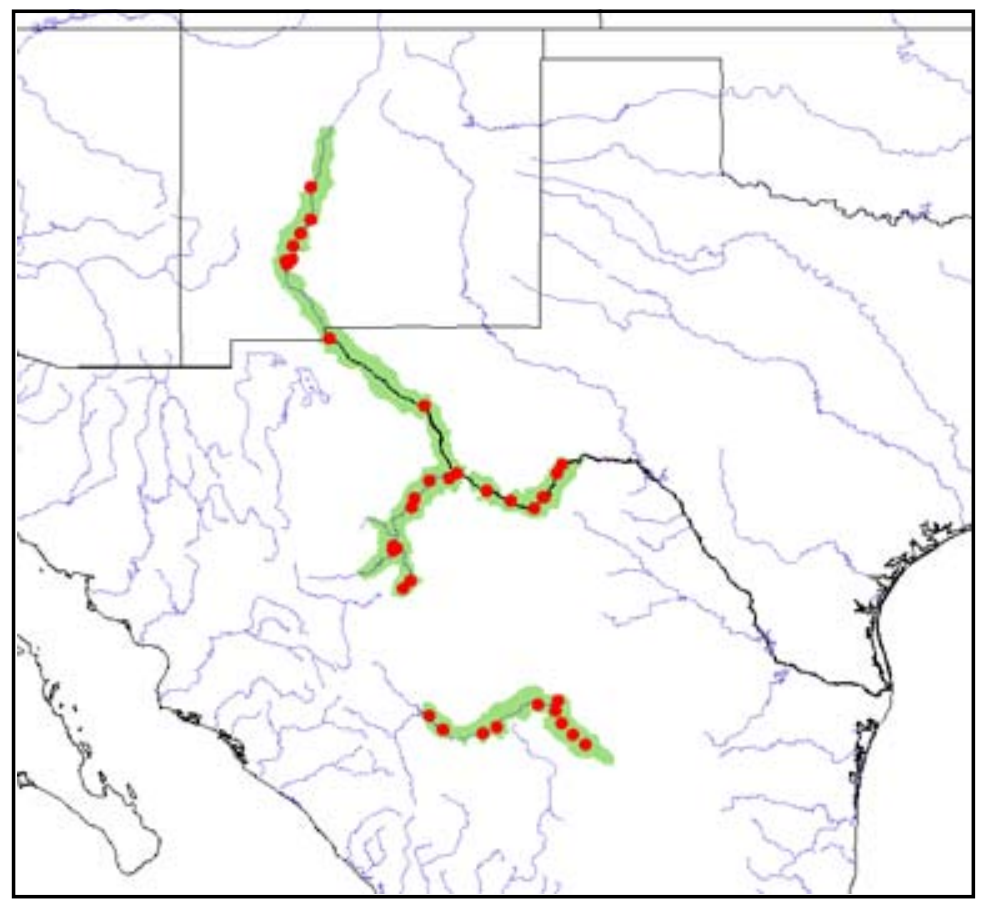

Figure 5. Distribution of Trachemys gaigeae in the southwestern USA (New Mexico and Texas) and northeastern Mexico. Trachemys g. gaigeae is the disjunct northern distribution, T. g. hartwegi the disjunct southern range. Red points $=$ museum and literature occurrence records based on Iverson (1992) plus more recent and authors' data; green shading = projected distribution based on GIS-defined hydrologic unit compartments (HUCs) constructed around verified localities and then adding HUCs that connect known point localities in the same watershed or physiographic region, and similar habitats and elevations as verified HUCs (Buhlmann et al., in press), and adjusted based on authors' data.

terrain, over which it is unlikely that any trachemyd turtle would traverse (Ward 1980). The Río Nazas runs southward from Lázaro Cárdenas Reservoir toward Torreon. The Río del Oro begins at the base of the Sierra del Oso, running into the reservoir from the north, but is dry most of the year, inhibiting the movement of aquatic turtles. Any connection to the Río Fuerte (a river of the Pacific slope) or Río Conchos drainages in Recent time is highly unlikely, given that present day conditions have apparently existed since the early Pleistocene (Martin and Harrell 1957; Fishbein 1976). Thus, T. g. hartwe $i$ likely has been isolated from other Trachemys for hundreds of millenia.

Based on the available genetic evidence and long-term allopatry, the two subspecies of T. gaigeae could be recog- nized as separate and monotypic species (e.g., Forstner et al. in press) although additional study is needed (Stephens and Wiens 2003). The taxonomic history of $T$. gaigeae was discussed by Ernst (1992), Seidel et al. (1999), and Stuart and Ernst (2004).

Preliminary genetic data from the Rio Grande populations suggest that $T$. g. gaigeae in New Mexico are divergent from populations in Texas (Jackson et al. 2007). One hypothesis for these genetic differences is that populations in these two states are now separated by habitat loss. Populations in the Big Bend region are presumably genetically contiguous with those in the Río Conchos, but are also parapatric with native T. s. elegans in the Rio Grande below Big Bend, where some hybridization does occur (Forstner et al. in press). Hybridiza-
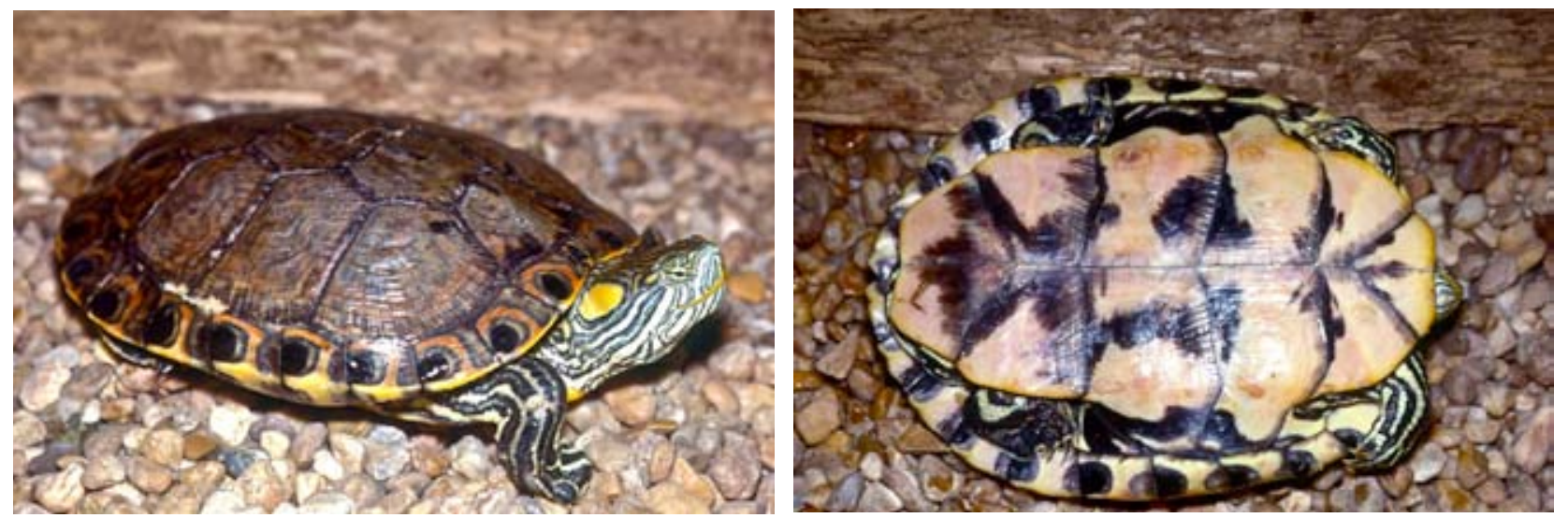

Figure 6. Trachemys gaigeae hartwegi, adult from Río Nazas, Presa Francisco Zarco, near Nuevo Graseros, Durango, Mexico. Photos by John B. Iverson. 
tion with non-native T. s. elegans also might have differential effects on small, isolated populations.Additional genetic studies are needed that include material from the Río Conchos.

The most recent proposals for standard common names for the species and its subspecies are in Iverson et al. (2008), Collins and Taggart (2009), and Liner and Casas-Andreu (2008).

Description. - Trachemys gaigeae is a medium-sized semi-aquatic emydid. The maximum straight-line carapace length (CL) recorded in $T$. g. gaigeae is $270 \mathrm{~mm}$ in females and $221.5 \mathrm{~mm}$ in males (Stuart et al. 1993; Stuart 1998); in T. g. hartwegi, maximum recorded size is $308 \mathrm{~mm} \mathrm{CL}$ in females and $149 \mathrm{~mm}$ CL in males (Legler 1990; Conant 1997). Both sexes of T. g. gaigeae in New Mexico attain a greater CL than documented in Texas or Chihuahua (Legler 1960c; Forstner et al. in press).

The large, supratemporal (postorbital) spot is much wider than (and usually separate from) nearby head stripes, orange to yellow-orange, ovoid or tear-drop shaped, and usually does not contact the orbit of the eye. A much smaller spot that contacts the posterior edge of the orbit may also be present. The carapacial pattern ranges from nearly patternless (in $T$. g. hartwegi) to a reticulate arrangement of ocellate yelloworange lines with dark borders against an olive or olivebrown background (in $T$. g. gaigeae). The plastral pattern, most distinct in juveniles, consists of a mostly symmetrical dendritic arrangement of two or more concentric dark lines centered on the shell midline and extending laterally along the inter-scute seams (Stuart and Ernst 2004), although the plastral pattern may be more extensive in some individuals (Ward 1980).

The carapace is typically smooth (not rugose) in $T . g$. gaigeae, although radial corrugations may be present and distinct on vertebral scutes in adult $T$. g. hartwegi. The vertebral keel is blunt or absent in adults, and the posterior marginals are moderately serrate. Plastron length is greater than $89 \%$ of the carapace length. The underlap of the cervical scute is relatively short (less than $3.5 \%$ of carapace length). The squamosal bone is tapered posterodorsally rather than blunt. The pygal bone is elongate and extends beyond the marginal-vertebral seam. The mandibular tomium is not serrate, and the ventral surface of the mandible is rounded (Stuart and Ernst 2004). More extensive description of the skull and mandible is in Ward (1980).

Sexual dimorphism is evident in mature specimens. Males are smaller than females and have long, thick tails with the vent beyond the carapacial rim. The carapace of females is visibly more domed and the plastron of males is slightly concave. In $T$. g. gaigeae, females tend to retain the juvenile color pattern into adulthood, although secondary deposition of melanin may partially obscure the plastral pattern (Seidel et al. 1999).

Mature male $T$. g. gaigeae exhibit progressive ontogenetic melanization (sensu Lovich et al. 1990) which results in a gradual reorganization and fading of the juvenile color pattern on the skin and shell but no apparent net increase in dark coloration as seen in T. scripta. Old male $T . g$. gaigeae typically have a mostly yellowish plastron with black concentrated along the inter-scute seams, a blotchy lichen-like pattern on the carapace, darkened foreclaws, a pale tomium, and a barely discernible post-orbital spot (Stuart 1998). Ontogenetic melanization has not been described in T. g. hartwegi. Males in both subspecies lack the elongated foreclaws characteristic of male T. scripta.

Hatchlings of T. g. gaigeae from New Mexico average $29.0 \mathrm{~mm} \mathrm{CL}$ and $6.0 \mathrm{~g}$ and have a dense reticulate pattern on the carapace and a plastral pattern similar to that described for juveniles. The colors of hatchlings are muted: the carapace is grayish olive, the plastron and stripes on the extremities are dull cream, and the orange coloration seen in more mature individuals is lacking (Morjan and Stuart 2001, Stuart and Painter 2006).

The distinctive isolated post-orbital spot in T. gaigeae is present in ca. $88 \%$ of all adults, juveniles, and hatchlings from New Mexico, although infrequently at least one spot is contiguous with a neck stripe or extends anteriorly to contact the orbit (Stuart 1998). Specimens of $T$. g. gaigeae are often confused with $T$. s. elegans from the Pecos River of New Mexico and lower Rio Grande of the USA - Mexico border (Legler 1960a, Seidel et al. 1999, Stuart 2000). These "Rio Grande sliders," which resemble T. gaigeae in possessing an isolated post-orbital spot but have a skin and shell pattern similar to T. s. elegans from the Mississippi River basin, have been misidentified as T. gaigeae (e.g., Vetter 2004) or interpreted as elegans $\mathrm{x}$ gaigeae intergrades (e.g., Hamilton 1947, Williams 1956, Degenhardt and Christiansen 1974).

Distribution. - Trachemys gaigeae occurs in the Rio Grande (= Río Bravo del Norte), Río Conchos, and Río Nazas drainage systems of the southwestern United States (Texas, New Mexico) and northern Mexico (Chihuahua, Coahuila, Durango). Populations of T. g. gaigeae occur in the Rio Grande from Bosque del Apache National Wildlife Refuge, Socorro County, New Mexico, downstream at least to the Brewster-Terrell county line, Texas; and in the Río Conchos from near La Cruz (Presa La Boquilla), Chihuahua, downstream to the confluence with the Rio Grande near Ojinaga. The subspecies likely also occurs in at least the lower part of the Río San Pedro, a tributary of the Río Conchos (Chrapliwy and Fugler 1955). In the Rio Grande, an apparent hiatus in suitable habitat for breeding populations occurs from Caballo Dam, Sierra Co., New Mexico, downstream to near Fort Quitman, Hudspeth Co., Texas, although a few individuals have been recorded from this reach (Stuart and Ernst 2004; Forstner et al. in press). A similar hiatus might exist between populations near Fort Quitman and Presidio, Texas. Most records along the USA - Mexico border are downstream of the confluence of the Río Conchos which provides most of the surface water to the lower reach of the Rio Grande (Forstner et al. in press).

Trachemys $g$. hartwegi has a range disjunct from T. g. gaigeae in the Río Nazas internal drainage system of Durango and Coahuila (Smith and Smith 1980; Ward 1980; Legler 1990). Specimens have been obtained from 
Durango downstream of Presa Lázaro Cárdenas (= Presa El Palmito; type locality) and the vicinities of Lerdo, Nazas, and Rodeo; and from Coahuila in the vicinity of San Pedro de Las Colonias (Legler 1990). Distribution limits in this river have not been well-defined and habitat loss has possibly eliminated some populations. It is apparently absent from the nearby Río Aguanaval closed basin (Conant 1963, 1977).

Habitat and Ecology. - Trachemys gaigeae is a river turtle (Moll and Moll 2004) and occupies higher order streams within the Chihuahuan Desert which, at least prior to human intervention, were subject to extreme fluctuations in flow. Although Minton (1959) suggested that fluctuating rivers might adversely affect this species, it appears to be well-adapted to this environment. In the narrow river canyons of the Big Bend region, the Rio Grande channel is almost the only available aquatic habitat, but in New Mexico it also uses ponds, marshes, and canals up to $2 \mathrm{~km}$ from the river. Riverside sloughs are also used along the Río Conchos (Smith et al. 1963). Two main stem reservoirs on the Rio Grande also provide habitat for this species, especially in the shallower upper ends of these water bodies where drowned trees and sediment deposition creates a diverse environment for foraging and basking (Stuart 1998). Riverine habitat is often bordered by a narrow gallery for-
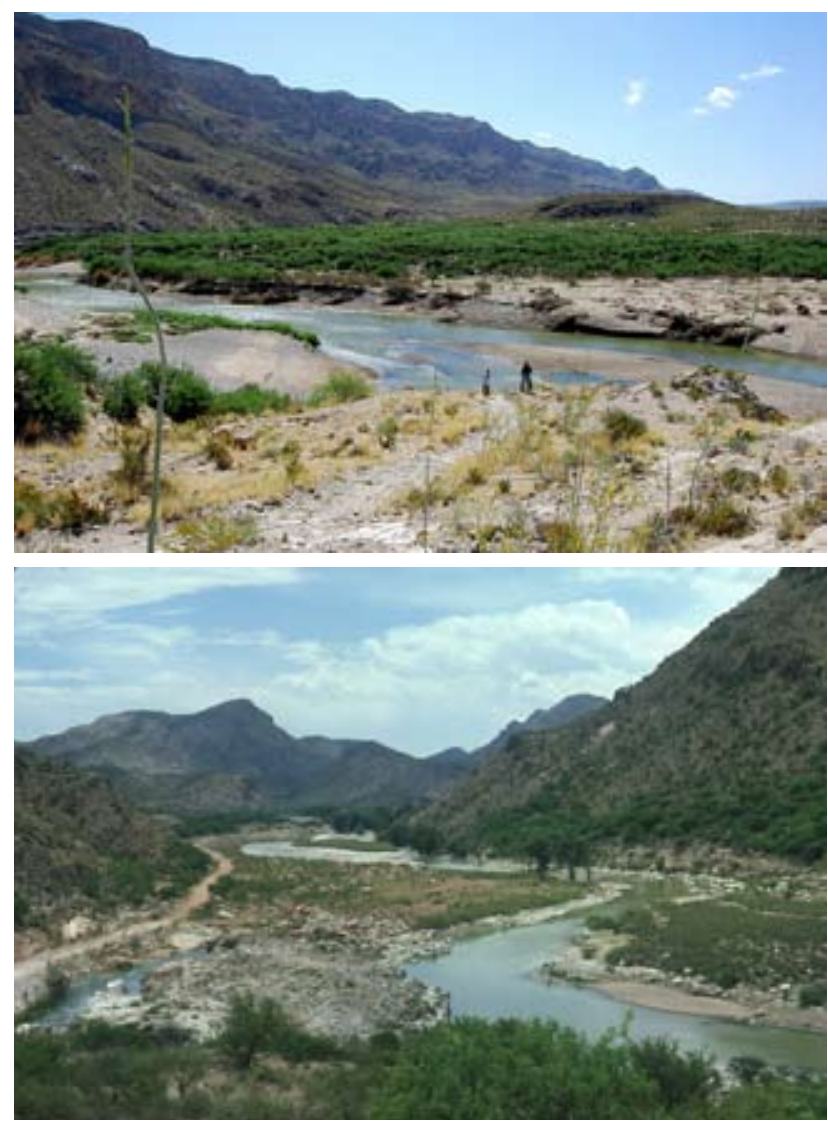

Figure 7. Top: Habitat of Trachemys gaigeae gaigeae near type locality, Rio Grande at Boquillas, Brewster Co., Texas, USA. Photo by Jennifer Wallin Oliver. Bottom: Habitat of Trachemys gaigeae hartwegi near type locality, Río Nazas below Presa Lázaro Cárdenas (Presa El Palmito), Durango, Mexico. Photo by John B. Iverson. est of cottonwoods and willows (Stuart 1998), or (in the Río Nazas) Mexican cypress (Conant 1963, Legler 1990). Adults and juveniles are most abundant in deep (>1 m) perennial waters, both lotic and lentic, although shallow, intermittent waters also may be used when nearby deeper waters are also available. Water turbidity is usually high and the substrate in these various habitats can consist of sand, silt, stones, or bedrock (Stuart 1995).

Habitat use in the Ríos Conchos and Nazas has not been described in detail, although the species has been taken in free-flowing reaches of both rivers (Legler 1960c, 1990) and might also use man-made impoundments within and near river channels, as do other Mexican species of Trachemys (Legler and Webb 1970). The habitat of hatchling T. gaigeae is not known but possibly includes the littoral zones or shallow backwaters of rivers and impoundments.

Activity, Movements, and Behavior. - In New Mexico, at the northern extreme of the species' range, T. gaigeae can be active almost year-round except during freeze periods in winter.Like other sliders, T. gaigeae is a basking species and uses partially submerged rocks or logs, matted vegetation, riverbanks, and other available perches for sunning. Aquatic basking at the water surface is also used where terrestrial basking sites are limited (Legler 1960c; Stuart, pers.obs.). Basking has been observed in New Mexico from at least
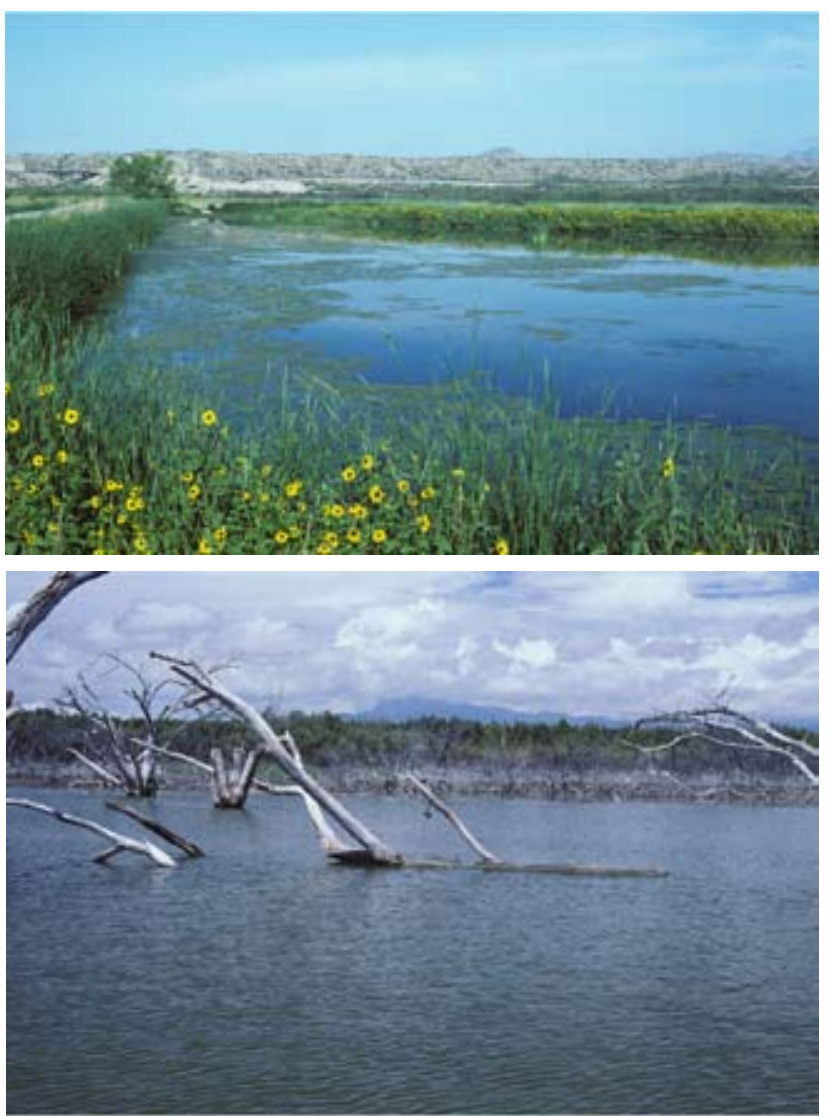

Figure 8. Habitats of Trachemys gaigeae gaigeae in New Mexico, USA, at Bosque del Apache National Wildlife Refuge (top) and Elephant Butte Reservoir (bottom). Photos by J.N. Stuart. 
February through November, but is less frequent during the heat of mid-summer in the Rio Grande (McCrystal 1991, Stuart 1998). Feeding likely occurs mostly in the morning and late afternoon (Ernst and Lovich 2009), but little information is available on diel activity.

Home ranges have not been studied, although some individuals have been recaptured at the same locations for multiple years (Stuart 1998, Forstner et al. in press). Annual movements of up to $6 \mathrm{~km}$, presumably via a canal, were detected at Bosque del Apache National Wildlife Refuge (Stuart 1998) whereas much longer annual dispersals (up to 56 river $\mathrm{km}$ ) have been documented along the Rio Grande in Texas (Jackson et al. 2007). Overland dispersal, other than for nesting, is uncommon but has been observed in New Mexico (Stuart, pers. obs.)

Stuart (1998) noted that large female $T$. g. gaigeae can often be aggressive when handled, frequently struggling and attempting to bite. When prodded, a female on land will often pivot to face the threat. This aggressive behavior was rarely seen in male conspecifics or T. s. elegans of either sex in New Mexico, which tend to withdraw into the shell.

Diet. - Carr (1952) suggested T. gaigeae is largely carnivorous, whereas Price and Hillis (1989) considered adults to be exclusively herbivorous. The species is actually omnivorous and its diet resembles that of other sliders (Parmenter and Avery 1990). Hatchlings and juveniles are insectivorous or carnivorous; in captivity they will feed on small aquatic invertebrates and pieces of meat or fish (Stuart and Painter 2002). Forstner et al. (in press) observed juveniles foraging for aquatic insects in riffle areas of the Rio Grande. Adults are mainly herbivorous. In New Mexico, the adult diet includes filamentous green algae (Oedogonium sp., Mougeotia sp., and possibly Rhizoclonium sp.), aquatic vascular plants (Potamogeton spp.,Zannichellia sp., and Myriophyllum sp.), and muskgrass (Chara vulgaris). Secondary food items, possibly ingested with filamentous algae or vascular plants, include diatoms (Gomphonema, Cocconeis, and Epithemia), desmid and coccoid green algae, and unidentified pollen. In Texas, adults are known to eat new shoots of common reed (Phragmites australis) and possibly also river cane (Arundo donax) which might be the primary food plant available in some areas (Stuart and Painter 2002, Forstner et al. in press). In late summer, the beans of mesquite (Prosopis glandulosa) growing near water bodies are also consumed in the Big Bend region (J. Jackson, pers. comm.). Carrion, including fishes (Cyprinus carpio, Ictalurus sp., Micropterus sp.) and crayfish (Orconectes sp.), and insects are taken opportunistically by adults, and might provide an important food source, especially when aquatic vegetation is unavailable (Stuart and Painter 2002, Forstner et al. in press). Small organisms found in stomach contents of adults are presumably taken incidentally during consumption of vegetation, although some might be ingested via neustophagia (Stuart and Painter 2002). Juveniles and adults are attracted to hoop traps baited with meat, fresh or canned fish, lettuce, or watermelon (Legler 1960b, Degenhardt et al. 1996, Stuart and Painter 2002).
Mating Behavior. - Male courtship in T. gaigeae does not involve foreclaw titillation, as used by T. scripta and many other emydids, but resembles behaviors reported for other Mesoamerican sliders that lack elongated foreclaws (Fritz 1990, 1998; Seidel and Fritz 1997). A courting male approaches a submerged female from the front or side with the neck fully extended. When their heads are $<5 \mathrm{~cm}$ apart, the male initiates rapid nodding movements of his head and may simultaneously eject water from his nares. This behavior appears to be functionally analogous to foreclaw titillation. Male courtship has been observed in an outdoor artificial pond during January and February when water temperatures were $9-15^{\circ} \mathrm{C}$ (Stuart and Miyashiro 1998). Ward (pers.obs.) observed a male $T$. gaigeae approach a female $T$. s. scripta from the front, rub the female's head with his forefeet for 1-2 sec, and then bob his head up and down several times. The male repeated the actions several times over $9.5 \mathrm{~min}$, then abruptly turned nearly 180 degrees and swam away from the female. Copulation has not been described.

Female $T$. gaigeae may be responsive to the courtship of male $T$. scripta as evidenced by an observation of copulation between a captive female $T$. gaigeae and male T. s. elegans $\mathrm{x}$ gaigeae hybrid with elongated foreclaws (Stuart, pers.obs.). The courtship behavior in this male was not seen. Nearly all T. s. elegans $\mathrm{x}$ gaigeae hybrids that have been genetically analyzed possess only $T$. g. gaigeae mtDNA, suggesting that most hybrid events involve female $T$. g. gaigeae (Jackson et al. 2007, Forstner et al. in press).

Eggs and Clutch Sizes. - Legler (1960c) reported clutches of 6-11 oviductal eggs in four females (169-202 mm CL) collected from the Río Conchos on 26 June. In New Mexico, clutches of 6-29 eggs have been documented in gravid females (228-266 mm CL) captured between 19 May and 11 July (Morjan and Stuart 2001; Stuart and Painter 1997, 2006). The eggs $(\mathrm{N}=12$ clutches $)$ average $35.0 \mathrm{~mm} \times 22.5$ $\mathrm{mm}$ and $10.7 \mathrm{~g}$; the shell is flexible and parchment-like and appears pinkish white when freshly laid, eventually becoming chalky white. Egg mass index (EMI; mean individual egg mass X 100/spent female mass) for T. g. gaigeae falls midway between EMIs reported for American T. scripta and Central American Trachemys spp. However, relative clutch mass (RCM; clutch mass/spent female mass) is comparable to U.S. populations of T. scripta (Stuart and Painter 2006). The incubation period at $28-30^{\circ} \mathrm{C}$ in the laboratory averaged 60.8 days. Both maximal female size and clutch size in $T$. g. gaigeae appear to be greater in the northern part of the range (Stuart et al. 1993; Stuart and Painter 2006). Production of multiple clutches per year is unverified, although the presence of enlarged ovarian follicles of various sizes in dissected specimens (Legler 1990, Stuart and Painter 1997) suggests it is likely.

Nesting. - The only published observation of nesting is by Morjan and Stuart (2001) in New Mexico. A female (229 mm plastron length) was found travelling overland on 31 May (1610 h) and was observed excavating a nest site and ovipositing in a level area of sandy soil near a paved highway. The site had ca. $10 \%$ vegetation cover (no canopy) 
and was ca. $25 \mathrm{~m}$ from the nearest water. The nest chamber was $19 \mathrm{~cm}$ deep and contained 19 eggs. The observed nesting behavior, including touching the neck to the ground while searching and voiding on the plugged nest chamber, resembled stereotyped behaviors reported in other emydids. Hatchlings were observed in the nest chamber from 20 August through 16 January and were absent on 2 April (possibly due to predation), indicating that hatchlings of this species overwinter in the nest.

Sex Determination and Ratios. - Trachemys gaigeae presumably has temperature-dependent sex determination (type TSD-1a) as observed in other Trachemys (Ewert and Nelson 1991, Ernst and Lovich 2009). Mark-recapture studies in New Mexico indicated a 1:1 sex ratio at Bosque del Apache National Wildlife Refuge ( $\mathrm{N}=73$ adults) and 1.48:1 male-biased ratio at Elephant Butte Reservoir $(\mathrm{N}=$ 140 adults) (Stuart 1998). It is unknown if the male-biased ratio in the reservoir sample reflected the actual population structure or was an artifact of trapping effort (Gibbons 1990).

Growth, Maturation and Longevity. - Little information on growth rates or age at maturity is available. One recaptured immature female in New Mexico grew from 122 to $182 \mathrm{~mm}$ CL in a 2-yr period (Wilson et al. 1999).

In a study of melanism in T. scripta, Lovich et al. (1990) observed that the onset of male ontogenetic melanization (color pattern reorganization) in that species occurs at approximately the same size at which females become sexually mature. A similar ontogenetic pattern seems to occur in $T$. gaigeae. All male T. gaigeae examined in New Mexico exhibit advanced ontogenetic melanization at 180-190 $\mathrm{mm} \mathrm{CL}$, and males $>200 \mathrm{~mm}$ CL have lost all remnants of juvenile markings. Concurrently, females attain sexual maturity starting at 180-190 mm CL, and all females > $200 \mathrm{~mm}$ CL are reproductive (Stuart 1998). Based on size data from Texas (Forstner et al. in press), sexual maturity and melanization apparently occurs at smaller sizes in more southern populations.

A sexually mature female, estimated to be at least $7 \mathrm{yrs}$ old based on plastral annulae, was first captured at Bosque del Apache National Wildlife Refuge in 1994 when she was $230 \mathrm{~mm}$ CL, marked, and released. She was recaptured in 2009 and had an approximate CL of $240 \mathrm{~mm}$ (Stuart, unpubl. data).

Parasites, Disease, and Contaminants. - Endoparasites previously described from other emydids have been reported from T. gaigeae in New Mexico, including 7 species of coccidian (Eimeria spp.; McAllister et al. 1995); a trematode, Telorchis corti and nematode, Serpinema trispinosum (Wilson et al. 1999); and an acanthocephalan, Neoechinorhynchus emyditoides (McAllister et al. 2008). Parasitism by leeches (Placobdella spp.) has not been observed in T. gaigeae or sympatric aquatic turtle species in New Mexico (Stuart 1998), but is known in Texas populations (J. Jackson, pers. comm.). Epiphytic algae is commonly seen on sliders of all ages. Gaertner et al. (2008) described high levels of Salmonella bacteria in wild specimens of T. gaigeae in New Mexico and Texas. Garcia (1973) reported high concentrations of methylmercury in body tissues of $T$. gaigeae at Elephant Butte Reservoir that were indicative of bioaccumulation (possibly from scavenging fish carcasses), although without any apparent effect on the turtles. Shell necrosis, which has been reported for some other freshwater turtle species, has not been seen in $T$. gaigeae.

Aberrant Morphology. - Stuart and Painter (2008) reported kyphosis or kyphoscoliosis in $2.1 \%$ of all New Mexico adult or subadult specimens examined. Abnormally colored (xanthic) specimens were reported by Price and Hillis (1989) from New Mexico and Texas. Stuart (1998) described aberrant scutellation in some New Mexico specimens; the only such abnormality that was observed with some frequency was 1-2 small extra scutes on the midline of the plastron and at the attachment point for the yolk sac in hatchlings. These "umbilical scutes" were present in 33 of $235(14.0 \%)$ adults and juveniles and 12 of $123(9.8 \%)$ unsexed hatchlings. Among adult and subadult specimens that could be reliably sexed, 5 of 133 males (3.8\%) and 27 of 97 females $(27.8 \%)$ had this scute abnormality.

Associated Turtle Species. - Native aquatic turtles that co-occur with T. gaigeae in at least part of the species' range include Chrysemys picta, Apalone spinifera, Kinosternon hirtipes, and K. flavescens (Conant 1977, Iverson 1981, Degenhardt et al.1996). Sympatric species which are known or are likely to be introduced include Chelydra serpentina, Pseudemys gorzugi, and Trachemys scripta (Stuart 1995, Jackson et al. 2007).

Population Status. - Studies of population size and density are complicated by the fact that, in riverine parts of its range, habitat is highly attenuated and individuals, while generally sedentary, can disperse great distances in response to fluctuating water conditions. Relatively little information is available on population sizes in the United States, although the most robust populations are probably in Big Bend National Park and adjacent public lands along the Rio Grande in Texas (Forstner et al. in press). In New Mexico, the species appears to be most common in Elephant Butte Reservoir and small but stable populations occur at Bosque del Apache National Wildlife Refuge and between Elephant Butte and Caballo dams (Stuart 1998). Capture rates (number of turtles caught per hour of trapping effort) using baited hoop traps are generally low. In New Mexico, the rate was 0.01 at Bosque del Apache and slightly higher (0.02) at Elephant Butte Reservoir, where T. g. gaigeae was the most frequently captured species (Stuart and Painter, unpubl. data). During survey efforts in Texas and New Mexico, Forstner et al. (in press) had an overall capture rate of 0.04 which increased to 0.12 in areas considered to be optimal habitat. Variation in capture rates is likely influenced by the extent and permanence of aquatic habitat and is probably highest in localized deepwater sections of attenuated river channels. Recapture rates in these studies were too low to allow reliable density estimates. However, Forstner et al. (in press) suggested that perhaps 20-30 T. g. gaigeae could occupy a 2 river $\mathrm{km}$ reach of optimal 
habitat in the Rio Grande and extrapolated that 7500 T. $g$. gaigeae could occur along the Rio Grande and 2500 in the Río Conchos.

The apparent absence of populations along most of the Rio Grande between Caballo Dam and the confluence of the Río Conchos was discussed by Forstner et al. (in press). This reach of the river likely provided suitable habitat for T. gaigeae in the past, but has been impacted by upstream water withdrawals, channelization, and invasion of the riparian zone by saltcedar (Tamarix sp.), effectively isolating populations in Texas from those in New Mexico. A small population persists in an unchannelized reach of the Rio Grande in Hudspeth Co., Texas (Forstner et al. in press).

Little information is available for T. $g$. hartwegi in the Río Nazas, a river basin that has been impacted by water diversion. Legler (1990) noted that $T$. g. hartwegi might be nearing extirpation near San Pedro de las Colonias, was absent in the Laguna Viesca since 1960 (also noted by Iverson 1981), and is endangered throughout the Río Nazas basin except perhaps in the dam tailwater below Presa Lázaro Cárdenas, the type locality. Conant (1997) also suggested that the habitat at the type locality appears secure, presumably due to perennial water releases from the reservoir for downstream irrigation.

Systematic basking surveys of $T$. gaigeae have not been attempted, but could prove valuable in assessing the status of populations where trapping is not possible. Basking surveys would likely be most effective in late winter or early spring and in the fall when water temperatures are cooler and basking is physiologically more important (McCrystal 1991; Stuart, pers. obs.).

Threats to Survival. - Baillie and Groombridge(1996), based on assessment by the IUCN Tortoise and Freshwater Turtle Specialist Group, listed T. gaigeae as Vulnerable on the IUCN Red List due to its very limited range and threats to the quality of its habitat. The species occurs in river systems that have experienced extensive anthropogenic changes to hydrology and geomorphology to meet the demands of agriculture, municipal water supply, and flood protection (Schmidt et al. 2003). Degradation of riverine and riparian habitats caused by damming, surface water diversion, groundwater pumping, pollution, and river channelization is likely the greatest threat (Rosen 2008,Smith and Smith 1980). Invasive saltcedar (Tamarix sp.) also has contributed to habitat degradation in much of the Rio Grande and Río Conchos (Forstner et al. in press; Stuart, pers. obs.). Research on the native fisheries in the Ríos Conchos and Nazas indicates that increasing water consumption and pollution pose significant threats to the ecology of these Mexican rivers (Edwards et al. 2002, 2003; Contrereas-Balderas et al. 2005).

The impoundment of water behind large mainstem dams provides perennial aquatic habitat in New Mexico (and possibly in reservoirs on the Ríos Conchos and Nazas), but also degrades and fragments contiguous riverine habitat, thereby isolating populations. This is especially evident in the Rio Grande, where the population in the tailwater below Elephant Butte Dam and in Caballo Reservoir (a contiguous reach of ca. 40 river $\mathrm{km}$ ) is now isolated from upstream populations in Elephant Butte Reservoir (Stuart 1995). Below Caballo Dam, which diverts most of the river for agricultural use, there is little suitable habitat until the river is recharged by the Río Conchos above the Big Bend region (Forstner et al. in press).

Intensive manipulation of water levels in floodplain ponds at Bosque del Apache National Wildlife Refuge possibly results in some mortality of $T$. gaigeae but this has not been studied. Buhlmann and Gibbons (2006) attributed some mortality at the refuge to predation by coyotes as sliders travelled overland to escape drying ponds. Dispersing sliders are occasionally killed or injured by automobiles or farm equipment at the refuge (Stuart, pers. obs.).

A more recently identified threat to $T$. gaigeae is the introduction of non-native congeners. Introduced T. s. elegans have been found within the U.S. range of T. gaigeae since at least the 1970s (Degenhardt and Christiansen 1974; Stuart 1995; Degenhardt et al. 1996; Bartlett 2000). Although introduced T. s. elegans is known to be established at sites farther north in the Rio Grande (e.g., at Albuquerque, New Mexico; Stuart 2000), the presence of breeding populations of introduced sliders within the range of gaigeae is unconfirmed but appears likely. Hybridization between these taxa was suggested by Stuart (1995) and was subsequently confirmed in New Mexico and Texas (Seidel et al. 1999, Jackson et al. 2007, Forstner et al. in press). At present, the extent of hybridization and introgression in the U.S. appears to be limited, although preliminary data indicate some phenotypically "pure" $T$. gaigeae might possess $T$. s. elegans genes (Jackson et al. 2007). The status of nonnative sliders in the Ríos Conchos and Nazas is unknown, although Mexico has imported thousands of hatchling $T$. s. elegans from the United States (Warwick et al. 1990). Trachemys gaigeae potentially has an adaptive advantage over introduced T. scripta in its native range, which might limit the impact of hybridization or competition with nonnative sliders (Stuart 2000).

Collection of $T$. gaigeae for the commercial pet trade or as food has been reported but not well-documented. At least some specimens that are sold in the pet trade as Big Bend Sliders or Rio Grande Sliders are actually T. s. elegans from the lower Rio Grande and Pecos River of Texas and New Mexico (Stuart, pers. obs.). Reed and Gibbons (2002) and Schlaepfer et al. (2005) reported 300 T. gaigeae were exported from the U.S. for the pet trade during the period 1998-2002. Bonin et al. (2006) noted that this slider is much sought after by collectors and some populations have become depleted; they indicated the main threat is probably human consumption, although habitat degradation and pollution are also problems. Harris (2004) described butchered emydid remains, which likely included $T$. gaigeae, from a late 19th century historical site at Chinatown in El Paso, Texas. More recent, albeit anecdotal, evidence suggests the species is at least occasionally harvested for food in the Río Conchos (Legler 1960c) and Río Nazas (Smith and Smith 1980). Degenhardt and Christiansen (1974) noted that $T$. 
gaigeae and other aquatic turtles were taken occasionally as bycatch in nets by commercial fishermen in New Mexico reservoirs.

Little recent information is available on threats to $T . g$. hartwegi in the Río Nazas (Rosen 2008). Hydrologic and ecological changes that adversely affect native fisheries (Contreras-Balderas et al. 2005) might have lesser effects on aquatic turtles such as T. gaigeae, which have shown an ability to use reservoirs and dam tailwaters in New Mexico (Stuart 1995, 1998). The status of T. gaigeae in dammed reservoirs in Mexico, such as La Boquilla (Lago Toronto), La Colina, and Luis L. León on the Río Conchos, and Lázaro Cárdenas (El Palmito) and Francisco Zarco on the Río Nazas, is unknown.

Conservation Measures Taken. - The states of New Mexico and Texas have implemented regulations that prohibit the commercial harvest of $T$. gaigeae, although the species may be collected for personal use. In New Mexico (but not in Texas), it is classified as a Species of Greatest Conservation Need under the state's Comprehensive Wildlife Conservation Strategy (Wildlife Action Plan), a category that makes T. gaigeae a priority species for research and management but confers no legal protection.

Several populations of $T$. g. gaigeae occur within federal or state managed lands in the U.S. (e.g., Big Bend National Park, Bosque del Apache National Wildlife Refuge, Big Bend Ranch State Park, and Black Gap Wildlife Management Area) and Mexico (Cañon de Santa Elena and Maderas del Carmen protected areas). Habitat conservation and restrictions against collecting of wildlife on most of these lands provide some protection.

Permanent and intermittent ponds and wetlands at Bosque del Apache National Wildlife Refuge are managed primarily for waterfowl but are also used by aquatic turtles. Following recommendations by Stuart (1998) and Buhlmann and Gibbons (2006), the refuge installed partially-submerged logs in several perennial ponds to increase basking sites for T. gaigeae and to allow for easier monitoring of this species and non-native T. s. elegans. These basking sites also have increased awareness of the refuge's turtle fauna by both staff and visitors (Stuart, pers. obs.).

The species continues to be listed as Vulnerable on the IUCN Red List (www.iucnredlist.org), but needs updating, as its last assessment was completed in 1996. It is not listed by CITES on its Appendices.

Conservation Measures Proposed. - To protect the habitat of T. gaigeae, collaborative efforts should be supported that include a diversity of stakeholders and focus on sustainable use of water resources and the restoration and conservation of riverine and riparian habitats in both the U.S. and Mexico. Ongoing efforts to establish a binational park along the Rio Grande/Río Bravo del Norte at Big Bend would provide added protection to populations in this region. Other broad-scale conservation projects have been promoted for the Rio Grande and Río Conchos that would likely benefit this species (e.g.,Kelly 2001). The construction and maintenance of perennial ponds and oxbows adjacent to rivers can benefit this turtle where surface flows have been impacted by human use (Stuart 1998, Buhlmann and Gibbons 2006), although such sites might also conflict with conservation goals for other aquatic species if they become refugia for non-native fishes. Improvements in the management of existing main stem reservoirs to support aquatic wildlife, including $T$. gaigeae, also should be encouraged.

The introduction of T. scripta where T. gaigeae occurs poses a potential threat to the genetic integrity and persistence of this species. The effect of hybridization is possibly increased in parts of the range where $T$. gaigeae populations are small and isolated. Public land managers within the range of $T$. gaigeae should discourage release of non-native turtles by visitors and implement or support monitoring and control measures to eradicate non-natives, especially T. scripta (Stuart 1998, Buhlmann and Gibbons 2006).

Although research on $T$. gaigeae has increased greatly since the 1990s, the species remains one of the least known turtles in the United States (Ernst and Lovich 2009). Additional studies are needed on nesting habitat, hatchling microhabitat, population ecology, and the effects of habitat fragmentation. Further study of the contact zone between $T$. g. gaigeae and native T. s. elegans downstream of Big Bend would be valuable in understanding the genetics of this species. Available information on Mexican populations is very limited (e.g., Casas-Andreu 1967, Lemos Espinal and Smith 2007a, 2007b) and surveys of the Ríos Conchos and Nazas, including reservoirs on these rivers, should be a priority.

Trachemys gaigeae (as Pseudemys scripta gaigeae) was formerly considered a Category 2 Candidate for possible listing under the U.S. Endangered Species Act. It was removed from this status in the late 1980s (U.S. Fish and Wildlife Service 1989), apparently based on information from Texas which suggested that populations were more secure than previously believed (e.g., McCrystal 1991). A re-evaluation of the species' status by the Fish and Wildlife Service, based on information from recent studies, is warranted. In addition, an updated conservation assessment of T. g. hartwegi for the IUCN Red List is urgently needed.

Captive Husbandry. - Trachemys gaigeae is similar to the more familiar T. scripta in its captive husbandry requirements. An outdoor pond or livestock watering tank, equipped with a water-circulating pump and filter and a basking platform, provides suitable housing. Sliders kept indoors must be provided an artificial source of ultraviolet light. Captive adults will eat lettuce, aquatic vascular plants (e.g., Potamogeton and Myriophyllum), filamentous green algae, pieces of raw fish and shrimp, and commercial turtle pellets. Hatchlings can be maintained on frozen brine shrimp and bloodworms, both commercially available, small pieces of fresh fish, and aquatic insect larvae.

Eggs obtained from wild-caught gravid females via injection of oxytocin were incubated in moist perlite at $28-30^{\circ} \mathrm{C}$ with ca. $72 \%$ hatching success rate (Stuart 1998, Stuart and Painter 2006). We are unaware of any captive breeding projects involving T. gaigeae, but expect that experienced 
herpetoculturists familiar with other Trachemys would be successful with this species.

Current Research. - David Moore (Bureau of Reclamation, Denver, Colorado) is conducting a three-year radiotelemetry study, begun in 2007 , to assess habitat use, movements, and home ranges of $T$. gaigeae at Elephant Butte Reservoir and Bosque del Apache National Wildlife Refuge, New Mexico.Jake Jackson and Michael R.J.Forstner (Texas State University, San Marcos) and James R. Dixon (Texas A \& M University) are studying genetic variation within $T$. gaigeae in Texas and New Mexico and the extent of hybridization and introgression between this species and non-native T. s. elegans in the Rio Grande. They are concurrently investigating the natural history of this species via a mark-recapture study in Big Bend National Park (Jackson et al. 2007). We are unaware of any current research in Mexico.

Acknowledgments. - We thank C. Ernst, J. Jackson, and M. Seidel for comments on earlier versions of the manuscript. We also thank M. Dloogatch, C. Ernst, J. Iverson, C. Painter, M. Seidel, J. Jackson, M. Forstner, D. Moore, and J. Oliver for providing information.

\section{LITERATURE CITED}

BAILlie,J. ANDGRoOMBridge,B.(Eds.) 1996.IUCNRedList of Threatened Animals. Internatl. Union for the Conservation of Nature (IUCN), Species Survival Commission. Gland, Switzerland.

BARTLETt, D. 2000. Notes from the field. The geckos and sliders: surprising discoveries in Texas' Big Bend. Reptiles Magazine 8(3):30, 32-35.

Bonin, F., Devaux, B. And Dupré, A. 1996. Toutes les Tortues du Monde. Delachaux et Niestlé S.A., Lausanne, Switzerland.

Bonin, F., Devaux, B. and Dupré, A. 2006. Turtles of the World. Johns Hopkins University Press, Baltimore, Maryland.

BRINGsøE,H.2001.Trachemys Agassiz, 1857-Schmuckschildkröten, In: Fritz,U.(Ed.),HandbuchderReptilien und Amphibien Europas. Band 3/IIIA: Schildkröten (Testudines) I (Bataguridae, Testudinidae, Emydidae). AULA-Verlag, Wiesbaden/Wiebelsheim, Germany, pp. 517-523.

Buhlmann, K.A. And GibBons, J.W. 2006. Habitat management recommendations for turtles of conservation concern on National Wildlife Refuges. Final report to National Fish and Wildlife Foundation, Washington, D.C., 138 pp.

Buhlmann, K.A., Akre, T.S., Iverson, J.B., Karapatakis, D., MittermeIER,R.A.,GeORges,A.,Rhodin,A.G.J., vANDiJK,P.P., AND GIBBONS,J.W.In press.A global analysis of tortoise and freshwater turtle distributions with identification of priority conservation areas. Chelonian Conservation and Biology 8(2):in press.

CArr, A.F. 1952. Handbook of Turtles. The Turtles of the United States, Canada, and Baja California. Comstock Publication Associates, Cornell University Press, Ithaca, New York.

CAsas-Andreu,G. 1967.ContribuciónalConocimientodelas Tortugas Dulceacuicolas de México. Tesis Profesional,Facultad de Ciencias, Universidad Nacional Autónoma de México, México, D.F.

Chrapliwy, P.S. and Fugler, C.M. 1955. Amphibians and reptiles collected in Mexico in the summer of 1953. Herpetologica $11: 121-128$

Collins, J.T. AND TAGGart,T.W.2009. Standard common and current scientific names for North American amphibians, turtles, reptiles and crocodilians, 6thed. Center for North American Herpetology, Lawrence, Kansas.

Conant, R. 1963. Semiaquatic snakes of the genus Thamnophis from the isolated drainage system of the Río Nazas and adjacent areas in Mexico. Copeia 1963:473-499.

Conant, R. 1977. Semiaquatic reptiles and amphibians of the Chihuahuan Desert and their relationships to drainage patterns of the region. In: Wauer, R.H. and Riskind, D.H.(Eds.), Transactions of the Symposium on the Biological Resources of the Chihuahuan Desert Region, United States and Mexico, Sul Ross State University, Alpine, Texas, 17-18 October 1974. National Park Service, Proceedings and Transactions Series, No. 3, pp. 455-491.

Conant, R. 1997. A Field Guide to the Life and Times of Roger Conant. Selva, Canyonlands Publishing Group, L.C., Provo, Utah, $498 \mathrm{pp}$.

Contreras-Balderas, S., de Lourdes Lozano-Vilano, M. and García-Ramirez, M.E. 2005. Historical changes in the index of biological integrity for the lower Río Nazas, Durango, México. In: Rinne, J.N., Hughes, R.M., and Calamusso, B. (Eds.), Historical Changes in Large River Fish Assemblages of the Americas. American Fisheries Society Publication, pp. 225-237.

Degenhardt, W.G. and Christiansen, J.L. 1974. Distribution and habitat of turtles in New Mexico. Southwestern Naturalist 19:21-46.

Degenhardt, W.G., Painter, C.W. and Price, A.H. 1996. Amphibians and Reptiles of New Mexico. University of New Mexico Press, Albuquerque.

Edwards, R.J., Garrett, G.P. and Marsh-Matthews, E. 2002. Conservation and status of fish communities inhabiting the Río Conchos basin and middle Rio Grande, México and U.S.A. Reviews in Fish Biology and Fisheries 12:119-132.

Edwards, R.J., Garrett, G.P., ANd Marsh-Matthews, E. 2003. Fish assemblages of the Rio Conchos basin, Mexico, with emphasis on their conservation and status. In: Garrett, G.P. and N.L. Allan (Eds.), Aquatic Fauna of the Northern Chihuahuan Desert. Special Publications of the Museum of Texas Tech University, No. 46, pp. 75-89

ERNST, C.H. 1990. Systematics, taxonomy, variation, and geographic distribution of the slider turtle.In: Gibbons, J.W.(Ed.), Life History and Ecology of the Slider Turtle. Smithsonian Institution Press, Washington, D.C., pp. 57-67.

ERnst, C.H. 1992. Trachemys gaigeae. Catalogue of American Amphibians and Reptiles 538.1-538.4.

ERnst, C.H. And Lovich, J.E. 2009. Turtles of the United States and Canada, 2nd ed. Johns Hopkins University Press, Baltimore, Maryland, $840 \mathrm{pp}$.

Ewert, M.A. AND Nelson, C.E. 1991. Sex determination in turtles: diverse patterns and some possible adaptive values. Copeia 1991:50-69.

FisHBEIN,S.L. 1976.OurContinent:ANatural History of North America. National Geographic Society, Washington, D.C., 398 pp.

Forstner,M.R.J., DiXon,J.R.,GUERRA, T.M., Winters, J.M.,STUART, J.N., AND DAVIS, S.K. In press. Status of U.S. populations of the Big Bend slider (Trachemys gaigeae). In: Proceedings of the 6th Symposium on the Natural Resources of the Chihuahuan Desert, 15-16 October 2004. Chihuahuan Desert Research Institute, Fort Davis, Texas.

FrITZ, U. 1990. Balzverhalten und Systematik in der Subtribus Nectemydina, 1: Die Gattung Trachemys, besonders Trachemys scripta callirostris (Gray, 1855). Salamandra 26:221-245.

FRITZ, U. 1998. Courtship behavior and systematics in the subtribe Nectemydina 1 . The genus Trachemys, especially Trachemys 
scripta callirostris (Gray, 1855) [English translation of Fritz 1990]. Bulletin of the Chicago Herpetological Society 33:225-236.

FRITZ, U. AND HaVAš, P. 2007. Checklist of chelonians of the world. Vertebrate Zoology 52:149-368.

GAERTNER, J.P., HAHN, D., JACKSON, J., Forstner, M.R.J. AND Rose, F.L. 2008. Detection of salmonellae in captive and free-ranging turtles using enrichment culture and polymerase chain reaction. Journal of Herpetology 42:223-231.

GARCIA, J.D. 1973. A study of mercurials in the Elephant Butte Reservoir ecosystem. Unpublished Ph.D.Dissertation,University of New Mexico, Albuquerque.

GibBons, J.W. 1990. Sex ratios and their significance among turtle populations. In: Gibbons, J.W. (Ed.), Life History and Ecology of the Slider Turtle. Smithsonian Institution Press, Washington, D.C., pp. 171-182.

Hamilton, R.D. 1947. The range of Pseudemys scripta gaigeae. Copeia 1947:65-66.

HarRIS, A.H. 2004. Additions to the archaeological fauna of the former Chinatown section of El Paso, Texas. Southwestern Naturalist 49:534-538.

Hartweg, N. 1939. Anew American Pseudemys. Occasional Papers, Museum of Zoology, University of Michigan 397:1-4.

Holman, J.A. 1977. Comments on turtles of the genus Chrysemys Gray. Herpetologica 33:274-276.

IVERSON, J.B. 1981. Biosystematics of the Kinosternon hirtipes species group (Testudines: Kinosternidae).Tulane Studies in Zoology and Botany 23:1-74.

Iverson, J.B. 1992. A Revised Checklist with Distribution Maps of the Turtles of the World. Richmond, Indiana: Privately printed, $363 \mathrm{pp}$.

Iverson, J.B., Meylan, P.A. And SeIDEl, M.E. 2008. Testudines: Turtles. In: Crother, B.I. (Ed.). Scientific and Standard English Names of Amphibians and Reptiles of North America North of Mexico, with Comments Regarding Confidence in Our Understanding, 6th Ed. SSAR Herpetological Circular No. 37, pp 67-74.

JACKSON, J.T., ForstNer, M.R.J. AND DiXON, J.R. 2007. Evaluation of hybridization and introgression of Trachemys gaigeae and Trachemys scripta in Big Bend National Park. Unpublished project report to U.S. National Park Service, Big Bend National Park, Texas, $28 \mathrm{pp}$.

Jackson, J.T., Starkey, D.E., Guthrie, R.W. AND Forstner, M.R.J. 2008. A mitochondrial DNA phylogeny of extant species of the genus Trachemys with resulting taxonomic implications. Chelonian Conservation and Biology 7:131-135.

Kelly,M.E. 2001.The Río Conchos:APreliminary Overview. Texas Center for Policy Studies, Austin, Texas, 27 pp.

LeGLER, J.M. 1960a. A new subspecies of slider turtle (Pseudemys scripta) from Coahuila, México. University of Kansas Publications, Museum of Natural History 13:73-84.

LEGLER, J.M. 1960b. A simple and inexpensive device for trapping aquatic turtles. Proceedings of the Utah Academy of Science 37:63-66.

LEGLER, J.M. 1960c. Remarks on the natural history of the Big Bend slider, Pseudemys scripta gaigeae, Hartweg. Herpetologica 16:139-140.

LEGLER,J.M.1990.The genus Pseudemys in Mesoamerica: taxonomy, distribution, and origins. In: Gibbons, J.W. (Ed.), Life History and Ecology of the Slider Turtle. Smithsonian Institution Press, Washington, D.C., pp. 82-105.

LeGLer, J.M. AND WebB, R.G. 1970. A new slider turtle (Pseudemys scripta) from Sonora, México. Herpetologica 26:157-168.

Lemos Espinal, J.A. AND Smith, H.M. 2007a. Anfibios y reptiles del estado de Chihuahua, México/Amphibians and reptiles of the state of Chihuahua, Mexico. CONABIO, Universidad Nacional Autónoma de México, México, D.F., 613 pp.

Lemos Espinal, J.A. and Smith, H.M. 2007b. Anfibios y reptiles del estado de Coahuila,México/Amphibians and reptiles of the state of Coahuila, Mexico.CONABIO, Universidad Nacional Autónoma de México, México, D.F., 550 pp.

Liner, E.A. AND CASAS-ANDreu, G. 2008. Nombres Estándar en Español, en Inglés y Nombres Científicos de los Anfibios y Reptiles de México. Standard Spanish,English and Scientific Names of the Amphibians and Reptiles of Mexico,2nd ed.SSAR Herpetological Circular No. 38, 162 pp.

LOVICH,J.E.,GARSTKA, W.R.AND McCoY,C.J. 1990.The development and significance of melanism in the slider turtle. In: Gibbons, J.W. (Ed.), Life History and Ecology of the Slider Turtle. Smithsonian Institution Press, Washington, D.C., pp. 233-254.

Martin,P.S. and Harrell, B.E. 1957. The Pleistocene history of temperature biotas in Mexico and eastern United States. Ecology 38(3):468-479.

McAllister,C.T.,B ARger,M.A. AND Stuart, J.N. 2008. Neoechinorhynchus emyditoides Fisher, 1960 (Acanthocephala: Neoechinorhynchidae) from the Mexican Plateau Slider, Trachemys gaigeae (Testudines: Emydidae), in New Mexico, U.S.A. Comparative Parasitology 75:135-137.

McAllister, C.T., Stuart, J.N., AND Upton, S.J. 1995. Coccidia (Apicomplexa: Eimeriidae) from the Big Bend slider, Trachemys gaigeae (Testudines: Emydidae), in New Mexico. Journal of Parasitology 81:804-805.

MCCRYstAL, H.K. 1991. The herpetofauna of the Big Bend region. Sonoran Herpetologist 4:137-141.

Minton, S.A. 1959. Observations on amphibians and reptiles of the Big Bend region of Texas. Southwestern Naturalist 3:28-54.

Moll, D. And Moll, E.O. 2004. The Ecology, Exploitation, and Conservation of River Turtles. Oxford University Press, New York, New York.

Moll, E.O. AND LeGLER, J.M. 1971. The life history of a neotropical slider turtle, Pseudemys scripta (Schoepff), in Panama. Bulletin of the Los Angeles County Museum of Natural History, No. 11, $102 \mathrm{pp}$.

Morjan, C.L. and Stuart, J.N. 2001. Nesting record of a Big Bend slider turtle (Trachemys gaigeae) in New Mexico, and overwintering of hatchlings in the nest. Southwestern Naturalist 46:230-234.

Parmenter, R.R. ANDAvERY,H.W. 1990. The feeding ecology of the slider turtle. In: Gibbons, J.W. (Ed.), Life History and Ecology of the Slider Turtle. Smithsonian Institution Press, Washington, D.C., pp. 257-266.

Price, A.H. AND HiLlis, D.M. 1989. Biochemical genetics and taxonomic status of Trachemys gaigeae and of the Trachemys scripta complex in Texas. Abstracts, First World Congress of Herpetology, Canterbury, United Kingdom.

ReEd, R.N. and Gibbons, J.W. 2002 . Conservation status of live U.S. nonmarine turtles in domestic and international trade.Final report to U.S. Department of Interior, Fish and Wildlife Service, 86 pp.

Rosen, P.C. 2008. Aridland turtles in southwestern North America II. A review of conservation status and problems. Sonoran Herpetologist 21:130-135.

SchlaEPFER,M.A.,Hoover,C., AND Dodd,C.K.,JR. 2005.Challenges in evaluating the impact of the trade in amphibians and reptiles on wild populations. BioScience 55:256-264.

Schmidt, J.C., Everitt, B.L., AND Richard, G.A. 2003. Hydrology and geomorphology of the Rio Grande and implications for river rehabilitation. In: Garrett, G.P. and Allan, N.L. (Eds.), Aquatic Fauna of the Northern Chihuahuan Desert. Special Publications 
of the Museum of Texas Tech University, No. 46, pp. 25-45.

SEIDEL, M.E. 2002. Taxonomic observations on extant species and subspecies of slider turtles, genus Trachemys. Journal of Herpetology 36:285-292.

SeIDEl, M.E. And ERnst, C.H. In press. Trachemys. Catalogue of American Amphibians and Reptiles.

SeIDEL, M.E. AND Fritz, U. 1997. Courtship behavior provides additional evidence for a monophyletic Pseudemys, and comments on Mesoamerican Trachemys. Herpetological Review 28:70-72.

Seidel, M.E., Stuart, J.N. And Degenhardt, W.G. 1999. Variation and species status of slider turtles (genus Trachemys) in the southwestern United States and adjacent Mexico. Herpetologica 55:470-487.

Smith, H.M. AND Smith, R.B. 1980. Synopsis of the Herpetofauna of Mexico. Vol. VI. Guide to Mexican Turtles. Bibliographic Addendum III. John Johnson, North Bennington, Vermont.

Smith, H.M., Williams, K.L., AND Moll, E.O. 1963. Herpetological explorations on the Río Conchos, Chihuahua, México. Herpetologica 19:205-215.

STARKEY,D.E. 1997. Molecular systematics and biogeography of the New World turtle genera Trachemys and Kinosternon.Unpublished Ph.D. Dissertation, Texas A\&M University, College Station.

Stejneger, L. ANd BARbour, T. 1939. A Check List of North American Amphibians and Reptils, 4th Ed. Harvard University Press, Cambridge, Massachusetts.

StePhENS, P.R. AND WIENs, J.J. 2003. Ecological diversification and phylogeny of emydid turtles. Biological Journal of the Linnean Society 79:577-610.

StUART, J.N. 1995. Notes on aquatic turtles of the Rio Grande drainage, New Mexico. Bulletin of the Maryland Herpetological Society 31:147-157.

STUART, J.N. 1998. Natural history aspects of the Big Bend slider, Trachemys gaigeae, in New Mexico. Final project report to New Mexico Department of Game andFish,SantaFe and U.S. Fish and Wildlife Service, Bosque del Apache National Wildlife Refuge, Socorro, New Mexico, 43 pp.

STUART, J.N. 2000. Additional notes on native and non-native turtles of the Rio Grande drainage basin, New Mexico. Bulletin of the Chicago Herpetological Society 35:229-235.

Stuart, J.N. And ERnSt, C.H. 2004. Trachemys gaigeae. Catalogue of American Amphibians and Reptiles 787.1-787.6.

StUART, J.N. AND MiYashiRo, J.B.M. 1998. Trachemys gaigeae (Big Bend Slider). Courtship behavior. Herpetological Review 29:235-236.

StUART, J.N. AND PAinter, C.W. 1997. Trachemys gaigeae (Big Bend Slider). Reproduction. Herpetological Review 28:149-150.

Stuart, J.N. And Painter, C.W. 2002. Observations on the diet of Trachemys gaigeae (Testudines: Emydidae). Bulletin of the
Maryland Herpetological Society 38:15-22.

Stuart, J.N. And Painter, C.W. 2006. Trachemys gaigeae (Big Bend Slider). Reproductive characteristics. Herpetological Review 37:79.

StUART,J.N.ANDPAINTER,C.W.2008. Trachemys gaigeae gaigeae (Big Bend Slider). Kyphosis. Herpetological Review 39:218-219.

Stuart, J.N., Painter, C.W., and Stearns, B.C. 1993. Trachemys gaigeae (Big Bend Slider). Maximum size. Herpetological Review 24:32-33.

U.S. Fish AND WILdLIFE SERVICE. 1989. Endangered and threatened wildlife and plants; animal notice of review. Federal Register 54(4):554-579.

Vetter,H.2004.Turtles of the World. Vol.2,North America.Andreas S. Brahm, Edition Chimaira, ACS GmbH (Aqualog), Frankfurt am Main, Germany.

Walls, J.G. 1996, Cooters, Sliders and Painted Turtles. Neptune City, New Jersey: T.F.H. Publications Inc.

WARD, J.P. 1980. Comparative cranial morphology of the freshwater turtle subfamily Emydinae: an analysis of the feeding mechanisms and systematics. Unpublished Ph.D.Dissertation, North Carolina State University, Raleigh.

WARD,J.P.1984. Relationships of chrysemyd turtles of NorthAmerica (Testudines: Emydidae). Special Publications of the Museum of Texas Tech University, No. 21, 50 pp.

Warwick, C., Steedman, C., ANd Holford, T. 1990. Ecological implications of the red-eared turtle trade. Texas Journal of Science 42:419-422.

Weaver, W.G. JR. and Rose, F.L. 1967. Systematics, fossil history, and evolution of the genus Chrysemys. Tulane Studies in Zoology 14:63-73.

Williams, E.1956. Pseudemys scripta callirostris from Venezuela with a general survey of the scripta series. Bulletin of the Museum of Comparative Zoology 115:145-160.

Wilson, W.D., Hnida, J.A., and Stuart, J.N. 1999. Trachemys gaigeae (Big Bend Slider). Endoparasites. Herpetological Review 30:226.

\section{Citation Format for this Account:}

StUART, J.N. AND WARD, J.P. 2009. Trachemys gaigeae (Hartweg 1939) - Big Bend slider, Mexican Plateau slider, jicotea de la Meseta Mexicana. In: Rhodin, A.G.J., Pritchard, P.C.H., van Dijk, P.P., Saumure, R.A., Buhlmann, K.A., Iverson, J.B., and Mittermeier, R.A. (Eds.). Conservation Biology of Freshwater Turtles and Tortoises: A Compilation Project of the IUCN/SSC Tortoise and Freshwater Turtle Specialist Group. Chelonian Research Monographs No. 5, pp. 032.1-032.12, doi:10.3854/ crm.5.032.gaigeae.v1.2009, http://www.iucn-tftsg.org/cbftt/. 